\title{
Assessing Funding Mechanism Available for Mining Companies in Zimbabwe
}

\author{
Nyasha Kaseke, Gift Mapakame \\ University of Zimbabwe Business School Student, Freda Rebecca Mine, Zimbabwe \\ nykaseke@gmail.com, gmapakame@fredarebecca.co.zw
}

\begin{abstract}
The mining sector has been the cornerstone of economic growth in Zimbabwe hence funding becomes very crucial to resuscitate the economy. The study aimed to assess the funding mechanisms for the mining sector of Zimbabwe and the effect of these on the performance of the sector. A quantitative study was carried out in the mining sector. The research findings showed that respondents pointed out that the funding mechanisms used in the mining sector of Zimbabwe are project finance, finance by private equity, public bonds and loans from banks and other financial institutions. It was also revealed that over and above available mechanisms, investment in the mining sector is being influenced by Interest rate, Business economic empowerment policies, bank lending criteria and Technical information, simultaneously. Furthermore, the study established that the mining sector needs skilled and technical staff, Technical information, banks' lending criteria and Capital markets to get funding from investors. It was derived that, investment in the mining sector will increase production, product quality and profitability which in turn lead to infrastructural development. In addition, it is envisaged that funding will result in mining exports increase at the same time that new technologies are being introduced and the GDP is rising. Owing to the focus being exclusively on the funding of the mining sector, the study also recommended further studies on other factors, besides funding, that are affecting the performance of the sector.
\end{abstract}

Keywords: Funding mining Sector, Banks Lending Criteria, Capital Markets, Mining Sector Investment.

\section{Introduction}

Minerals and minerals exploration and extractions have gained momentum over the past decade in Southern African. This saw investment by domestic, regional and international investors reaching high levels. The investment is mainly driven by booming commodity prices, high demand for commodities with China emerging as one of the largest consumers, and the need to revive economies, with some economies basing on natural mineral resources, for example, Zimbabwe targeting a mining economy of US\$12billion by the year 2030. Governments have also supported the growth in investment through facilitating explorations, liberalizations of mining investment and privatization of state-owned mining companies. Zimbabwe with its vast mineral deposits, being a high ferrochrome producer, high concentration of platinum deposits, and one of the African gold high producers, have to increase production to achieve economic growth as targeted. These mineral deposits are supported by relatively good infrastructure, a large pool of skills and relatively favorable policies which seem to be advancing mineral extraction in Zimbabwe. However, in Zimbabwe, a lot of mining companies are failing to re-start operations or revamp key projects due to funding constraints that have impaired the sector and economy as a whole. The complete annihilation of output in this key sector has shown significant improvement. The mining sector is capital-intensive and is associated with high risk (both technical and economic).

A few resuscitated gold operations, improved platinum operations (new and existing mines) and diamond operations resulted in the country thriving in commodity markets. These characteristics present obstacles for many mining companies in terms of raising capital, especially for start-ups as there are a limited number of financiers who are willing to finance such Greenfield investments. Therefore, these challenges limit the sources of finance for mining investors in Zimbabwe and even in the region. In the past, the mining sector used to be financed through shareholder equity, debt financing, structured financing and syndicated loans but due to Zimbabwe's status as a struggling economy, characterized by limited Gross Domestic Product, budget deficits, negative current account, an underperforming banking sector and frail policy framework, the size of traditional investment in the mining sector has severely contracted (Zimbabwe Mining Development Company, 2015). There are conflicting expectations for the mining sector in Zimbabwe; on one hand, the mining sector is associated with high risk, limited production, low economic growth in the country, capital intensity of the sector and changing policies; and on the other hand, there is need to boost mining sector 
production, extensively exploit the mineral resources for growth and development. To achieve the latter, there is a need to increase investment by both the private sector and government in mineral extraction.

Background: Since the stimulation of the Zimbabwean economy by introducing multi-currency trading \& liberalization of minerals marketing, frontline investment poured into the mining sector boosting minerals output and mining gross domestic product contribution. The aim of the study is therefore to assess the forms of financing mechanisms for the mining sector to improve production. Gold, platinum, ferrochrome and diamond mining companies received extensive capital to either resuscitate or ramp up output leading to overall sector performance. However, the trend of growth of mining output reveals poor sector performance, declining tremendously from $37.4 \%$ in 2010 to as low as $-3.5 \%$ in 2014 owing to a variety of factors (Figure 1 below). These include under-capacitation of small-scale mining, prolonged mine closures, inadequate funding to develop new mines, payment currency for minerals (for example gold) and lack of capital to fund mineral output beneficiation assets. Revenues have also declined with $\$ 1.86 \mathrm{Bn}$ reported in 2015 against $\$ 1.9 \mathrm{Bn}$ in 2014 (Muganyi, 2016). It is undisputed that the sectors' performance declined due to financing constraints thereby contradicting the thrust to catalyze economic growth as a whole.

\section{Figure 1: Mining GDP Growth}

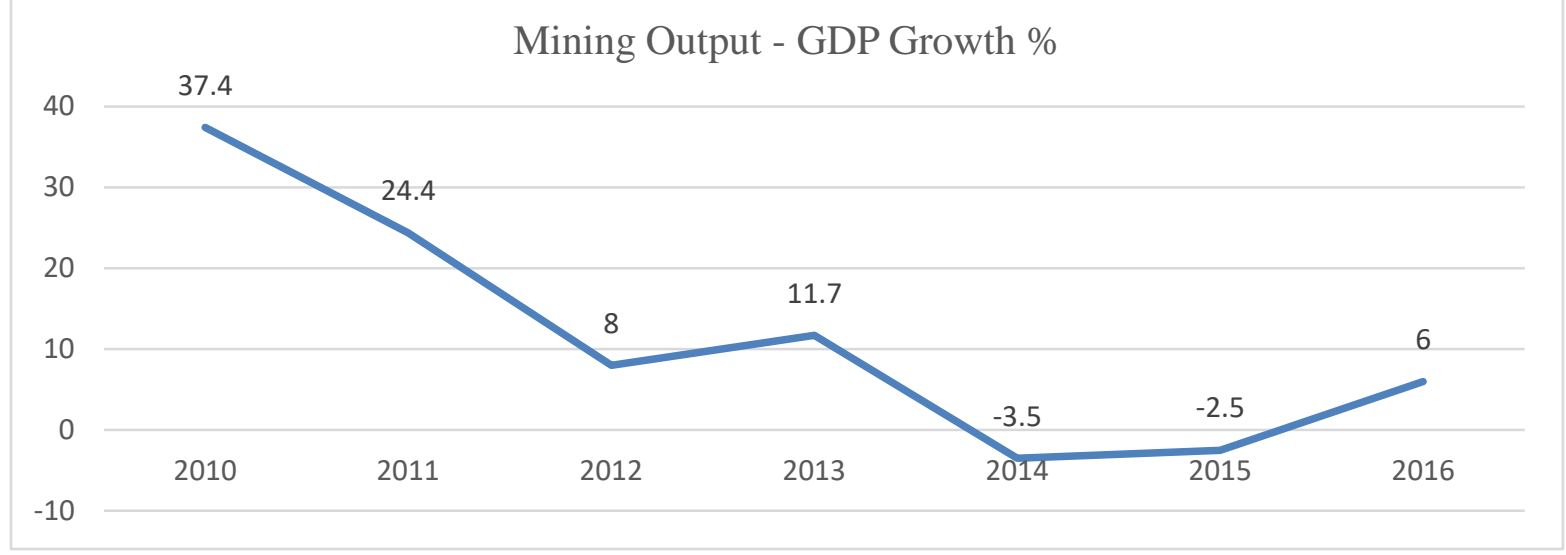

Source: MoF (2016)

Mine Closures and Idle Operations: The performance of the sector is critically inhibited by idle capacity due to capital shortages to bail out dormant assets. A snapshot of the mining sector output by the commodity of the pre-hyperinflation period and current period reveals a systematic gap that points out to a downward shift in operating entities. This signifies that it is critical to resuscitate existing mining operations to improve the performance of the sector. Figure 2 indicates how output in the key commodity facets has remained subdued even after the economy received stimulus from reforms that took place after hyperinflation in 2009. This infers that a substantial number of operations contributing to the sectors which recorded improved performance in the late 90 s remained under care and maintenance or on shutdown due to failure to secure funding for resuscitation despite sitting on vast exploitable mineral reserves. As a result, the overall performance of the sector continues to perform below projections. 
Figure 2: Gold Output Highlights



Source: Chamber of Mines (2015)

Gold output originates from both large-scale operators and rudimentary small-scale miners who have had no access to formal lines of credit to finance sustainable operations. Mining houses such as Metallon continue to lack expected contribution to output as they are running only 1 out of 4 large-scale operations.

Figure 3: Coal Output Highlights (from the Zambezi basin)

Coal

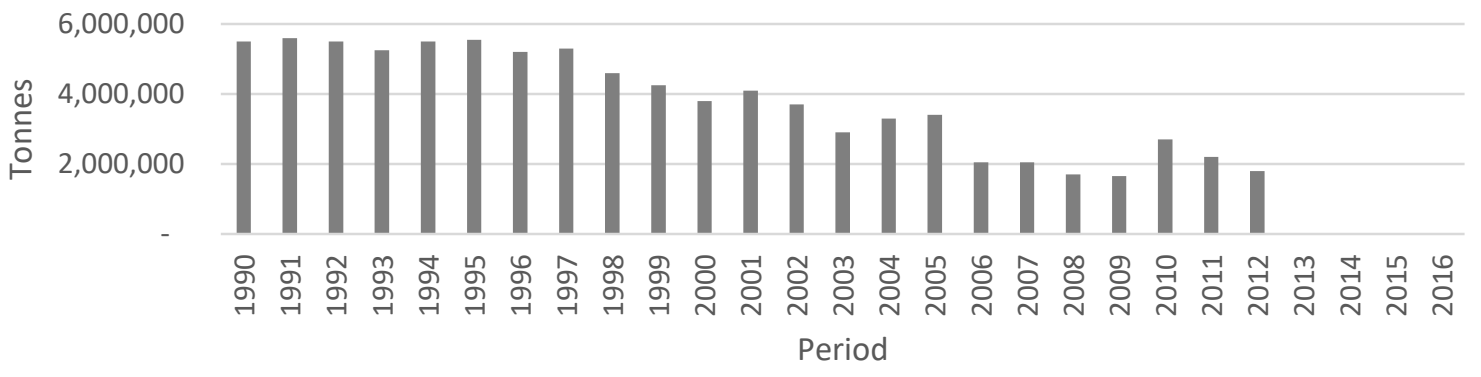

Source: Chamber of Mines (2015)

State-owned enterprise Hwange Colliery is struggling to secure funding for the underground operations which generates $75 \%$ of the revenue through exporting high-grade coking coal (Chamber of Mines, 2015). As a result, the commodity has low contribution to export earning since the output is dominated by power coal mined and sold locally to Zimbabwe Power Company for power generation. 
Figure 4: Asbestos Output from AA Mines

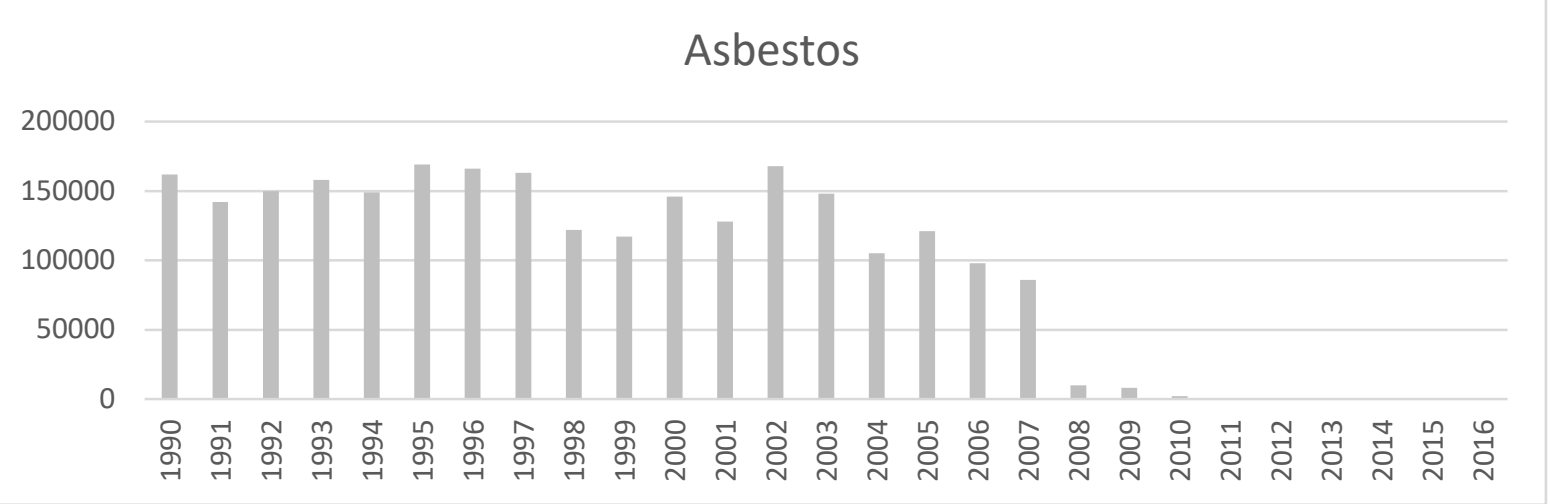

Source: Chamber of Mines (2015)

The once symbolic AA-Mines which exploited the vast fibrous deposits of Mashava for white asbestos have been reduced to shell infrastructure, with no reasonable prospects to obtain a suitable funding mechanism to re-capitalize owing to a prolonged shutdown which essentially depreciated all fixed assets and downgraded the investment grade to almost Greenfield.

Exploration and Mine Development: Though there is a demand to increase mineral output, explorations as the major starting point for mining have remained behind with reliance on past explorations. There was little investment in exploration over the last decade for Zimbabwe. The Department of Geological Survey failed to carry out its key role of geological mapping for the country over the past 10 years due to economic challenges (Chamber of Mines, 2015).

The Study Problem: The output from the mining sector is generally inconsistent with expectations substantiated by the reforms made by stakeholders in addressing policies and funding to capacitate the sector to achieve economic growth. To date, the performance of the mining sector remains subdued and exhibits a declining trend as several existing mines have failed to secure capital. Besides, crucial growth of the sector continues to spiral down commensurate with the lack of exploration spending and Greenfield project development. Ultimately, on the backdrop of an alarming funding deficit, miners are being driven out of the industry resulting in a poor performance outcome of the sector. Therefore, this research focuses on assessing funding mechanisms and options available to the mining sector in Zimbabwe.

\section{Theoretical Review}

This section presents literature on funding mechanisms, the factors affecting investment and its contribution to the performance of the mining sector.

Theories of Funding: Theories that explain funding are derived from the theories of investment (Nghifemwa, 2009). Three theories of investment highlighted the relationship between investment and industry performance. Agénor and Montiel (2009) note that funding of businesses is critical for any economy to grow. Little or no funding to businesses will result in little or no growth in the economy.

Marginal Efficiency Theory of Capital: This theory is based on the notion that investors look at the expected rate of return when considering investing in certain projects or institutions. In this case, the minimum expectation of the return is that rate that equates the cost of capital to the return on investment, simply put where the net present value is equal to or greater than zero (NPV $\geq 0$ ). Thus, any return above the cost of capital will give a positive marginal return. The economic environment also matters when making investment decisions. Chidhakwa (2016) highlighted that Zimbabwean banks have not been up-coming in lending mining companies due to economic challenges. Therefore, marginal efficiency is the discount rate that equates the present value of the expected revenue from an investment in the capital with the current supply cost of capital goods (Keynes, 1936). 
Tobin's Q-theory of Investment: The q-theory is based on the relationship between investment spending ratio and market value ratio determined by the additional unit of capital replacement cost (Tobin, 1969). This relationship will give a value often referred to as the q-ratio with a value of one (1) being the deciding level. A q-value above 1 means investment rises and below 1 means investment declines (Ferderer, 2009).

Accelerator Theory of Investment: This theory is based on the view that there is a relationship between investment and the performance of the firm or industry. The more the investment in the sector or industry, the more the growth. However, it is critical to note that there is the desired capital stock for a given level of output and interest rate. Beyond that, expected growth might not be realized. Also, an increase in demand for the product may increase demand for funding, as firms may be adjusting to meet the current demand.

Funding Mechanisms for the Mining Companies: Many funding mechanisms can impact the mining sector directly or indirectly. Vallerrie (2010) also added that there are several financing options available for mining projects. A study carried out by Leeman (2006) revealed that an effective funding mechanism can directly impact the performance of the mining sector. In addition, the Bankers Association of Zimbabwe (BAZ, 2014) highlighted that Zimbabwean mining company's need alternative funding mechanisms to perform in a depressed economy. Literature has shown various ways of financing mining companies. According to Mcmann (2010); Meyer (2014); Zhu (2011) and Vale (2012), there are various funding mechanisms which include; Project finance, Financing by IPO or Private Placement, Financing from Private Equity Funds, Royalty agreements, Escrow account arrangement, Streaming arrangements, Convertible loans, Public bonds, Loans from Banks and Other Financial Institutions, Joint venture partnerships, Off-take finance or contract financing, Corporate Bonds, Trusts, Equipment financing, Government Bonds, Export Credit Agencies and Financial Leasing. Meyer (2014) argued that the mining sector must be able to come up with suitable funding mechanisms.

Factors Affecting Funding: Eita and Du Toit (2007) found that the factors affecting funding are categorized according to three players in the mining sector; investor sphere, government sphere, and mine sphere.

Investor Sphere: As investment and funding largely emanate from different mechanisms all underpinned by investors looking for a return, it is prudent to note that, in the more standard Capital Asset Pricing Model (CAPM), an investment's riskiness is assessed against market return rather than consumption. Investors determine the country's risk. A country's risks in investment refer to the degree of uncertainty that exists about the occurrence of a future planned event. The capital budgeting decisions are also considered by the investor. Gawlik, (2008) and Pandey (2008) pointed out that when making capital budgeting decisions and investing in the mining projects, the following factors have to be considered: economic life of the mining projects; availability of the initial capital outlay; amount and timing of the cash flows; the need for additional capital requirements; the impact of the mining investment project on the entire firm; and how the initial capital outlay will be phased out.

Government Sphere: Chidhakwa (2016) affirmed that robust institutionalization of mining laws and competitive mining legislative framework is critical for local and international investors. These provide a conducive investment environment, simultaneously curtailing prejudice to national budget demands for investment funds. What investors want is a conducive environment and it can act as an incentive for investors even where there is no government support or incentives. The government must endeavor to promote efficient transactions by clearly stipulating, in black and white, what is acceptable and what is not. The government is a key player in motivating investment in the mining sector. Mothomogolo (2012) states that the government motivates investment through fast-tracking mining rights application process, providing investor conducive business economic empowerment policies, offering the security of tenure and transfer of title, refining royal tax and offering venture capital investments to allow the investor to claim funds.

Mine Operator Sphere: McMann (2010) indicated that the mine operator must ensure that there is technical information that is required to support funding available to mineral developers and financiers. The venture capital firms are also important to the investor through available companies or investors to enter into an agreement with. If partners are not willing to engage in contracts, then investors are affected negatively. Investors are also motivated by the banks' lending criteria. Skilled and technical staff must be availed. Mutiwa and Fondo (2015) argued that some projects need highly skilled and technical staff. In addition, there is a 
need for a clear framework for managing labor. Labour issues are critical in determining profit or losses to investors. The Labor movement creates a new center of power and employees may listen more to the leaders of the labor movement than their employers thereby creating confusion for investors.

Mining Business Performance: The classification of business performance is very subjective. Business performance in the financial sense as being characterized by-product sales performance, profitability and return on capital employed (ROCE) (Selvarajan et al., 2007; Hsu et al., 2007). Besides, return on investment (ROI other measures of financial performance that can be used are Net Income after tax (NIAT) and earnings per share (EPS) (Grossman, 2012). Qualitatively, performance can be measured based on subjective performance measures using the perceived performance approach (PPA). This measures performance using the Likert-like scaling approach based on top management perspectives (Selvarajan et al., 2007). However, this is always criticized as it is based on individual opinions without specific financial information even though top management is privileged to the organisation's financial information.

\section{Methodology}

A descriptive research design was used for this study. The research used quantitative data which was drawn from a sample of the staff and management of the mining sector. A survey was carried out in the mining sector. This study expects the staff and management in the mining sector to respond to a questionnaire on the funding mechanism on mining performance. A self-administered structured questionnaire was used as a research instrument for this research. The population of this study consisted of all mining companies affiliated with the Chamber of Mines of Zimbabwe. Approximately, there are 33 mining companies affiliated with the Chamber of Mines of Zimbabwe. The sample selection for this study was guided by Leedy and Omron (2001).

\section{Findings and Discussion}

Findings from statistical analysis by SPSS reflect the Cronbach's Alpha of 0.820 which reflects the consistency of the questionnaire to be able to be used in researches measuring the same variable.

\section{Appropriate Funding Mechanisms for the Zimbabwean Mining Sector}

Table 1: Statistics on Funding Mechanisms

\begin{tabular}{|c|c|c|c|c|c|c|}
\hline \multirow{2}{*}{$\begin{array}{l}\text { Funding Mechanism } \\
\text { Project Finance }\end{array}$} & \multicolumn{2}{|c|}{ Symbol N } & \multicolumn{3}{|c|}{ Minimum Maximum Mean } & \multirow{2}{*}{$\begin{array}{l}\text { Std. } \\
\text { Deviation } \\
.97872\end{array}$} \\
\hline & B1 & 20 & 2.00 & 5.00 & 4.3000 & \\
\hline Financing by IPO & B2 & 19 & 1.00 & 5.00 & 2.6842 & 1.37649 \\
\hline Financing from private equity funds & B3 & 20 & 1.00 & 5.00 & 3.5000 & 1.31789 \\
\hline Royalty agreement & B4 & 20 & 1.00 & 5.00 & 2.7000 & 1.38031 \\
\hline ESCROW accounts & B5 & 19 & 1.00 & 4.00 & 1.6842 & 1.10818 \\
\hline Streaming arrangements & B6 & 18 & 1.00 & 5.00 & 2.5000 & 1.38267 \\
\hline Convertible loans & B7 & 20 & 1.00 & 5.00 & 2.9000 & 1.44732 \\
\hline Public bonds & B8 & 20 & 1.00 & 5.00 & 2.4000 & 1.35336 \\
\hline Loans from banks & B9 & 20 & 2.00 & 5.00 & 4.4500 & .82558 \\
\hline Joint venture partnerships & B10 & 20 & 3.00 & 5.00 & 3.7000 & 86450 \\
\hline Off-take finances & B11 & 20 & 1.00 & 5.00 & 3.1000 & 1.02084 \\
\hline Corporate bonds & B12 & 20 & 1.00 & 5.00 & 3.4500 & 1.19097 \\
\hline Trusts & B13 & 20 & 1.00 & 4.00 & 2.4500 & .88704 \\
\hline Equipment financing & B14 & 20 & 3.00 & 5.00 & 4.3500 & .74516 \\
\hline Export credit agencies & B15 & 20 & 1.00 & 4.00 & 2.6500 & 1.13671 \\
\hline Development finance institution & B16 & 20 & 1.00 & 5.00 & 3.4000 & 1.35336 \\
\hline Government bonds & B17 & 20 & 1.00 & 5.00 & 2.9500 & 1.50350 \\
\hline Financial leasing & B18 & 20 & 1.00 & 5.00 & 3.2000 & 1.28145 \\
\hline
\end{tabular}


Table 1 revealed that whilst there was no least important funding mechanism, the less important funding mechanisms which were identified by this study were ESCROW accounts, Public bonds and Trusts. These were either uncommon or not preferred. On the other hand, the mechanisms which recorded high mean scores were Project Finance, Loans from banks and Equipment financing and are categorized as the more important funding mechanism. It is noted that none of the funding mechanisms involved qualified as most important implying that the sector adopts the funding mechanisms and complements each other without a single dominating mechanism.

Normality Tests: To ensure that the appropriate choice of data analysis techniques, normality tests were done to establish whether the distribution of the data availed suit to be analyzed by parametric or nonparametric analyses.

Table 2: Normality Tests - External Challenges

\begin{tabular}{|c|c|c|c|c|c|c|}
\hline \multirow[t]{2}{*}{ Funding Mechanisms } & \multicolumn{3}{|c|}{ Kolmogorov-Smirnova } & \multicolumn{3}{|c|}{ Shapiro-Wilk } \\
\hline & Statistic & df & Sig. & Statistic & Df & Sig. \\
\hline B1 & .317 & 18 & .000 & .722 & 18 & .000 \\
\hline B2 & .222 & 18 & .019 & .860 & 18 & .012 \\
\hline B3 & .197 & 18 & .064 & .849 & 18 & .008 \\
\hline B4 & .206 & 18 & .042 & .889 & 18 & .037 \\
\hline B5 & .434 & 18 & .000 & .610 & 18 & .000 \\
\hline B6 & .197 & 18 & .064 & .855 & 18 & .010 \\
\hline B7 & .211 & 18 & .034 & .865 & 18 & .015 \\
\hline B8 & .270 & 18 & .001 & .832 & 18 & .004 \\
\hline B9 & .320 & 18 & .000 & .726 & 18 & .000 \\
\hline B10 & .342 & 18 & .000 & .728 & 18 & .000 \\
\hline B11 & .237 & 18 & .009 & .895 & 18 & .048 \\
\hline B12 & .239 & 18 & .008 & .909 & 18 & .084 \\
\hline B13 & .220 & 18 & .021 & .891 & 18 & .040 \\
\hline B14 & .276 & 18 & .001 & .788 & 18 & .001 \\
\hline B15 & .287 & 18 & .000 & .833 & 18 & .005 \\
\hline B16 & .237 & 18 & .009 & .875 & 18 & .021 \\
\hline B17 & .201 & 18 & .054 & .867 & 18 & .016 \\
\hline B18 & .289 & 18 & .000 & .858 & 18 & .012 \\
\hline
\end{tabular}

From the above analyses, all the mechanisms except B12 violate the normality assumption which parametric tests assume the sample under test is from a population with normal distribution. It follows then that nonparametric analyses were the best analyses to use for data of this nature. An assessment of the forms of funding mechanisms available for the mining sector using Factor Analysis revealed the following results.

Table 3: Total Variance Explained - External Factors

\begin{tabular}{lllllll}
\hline Component & \multicolumn{3}{l}{ Initial Eigenvalues } & \multicolumn{3}{l}{ Extraction Sums of Squared Loadings } \\
& Total & \% of VarianceCumulative \% & Total & \% of Variance Cumulative \% \\
\hline 1 & 4.978 & 27.657 & 27.657 & 4.978 & 27.657 & 27.657 \\
2 & 3.015 & 16.751 & 44.408 & 3.015 & 16.751 & 44.408 \\
3 & 2.052 & 11.397 & 55.805 & 2.052 & 11.397 & 55.805 \\
4 & 1.706 & 9.478 & 65.283 & 1.706 & 9.478 & 65.283 \\
5 & 1.370 & 7.612 & 72.895 & 1.370 & 7.612 & 72.895 \\
6 & 1.215 & 6.751 & 79.647 & 1.215 & 6.751 & 79.647 \\
7 & .939 & 5.217 & 84.864 & & & \\
8 & .850 & 4.720 & 89.583 & & & \\
9 & .620 & 3.444 & 93.028 & & & \\
10 & .421 & 2.340 & 95.368 & & & \\
11 & .329 & 1.829 & 97.197 & & & \\
12 & .236 & 1.312 & 98.510 & & & \\
13 & .154 & .857 & 99.367 & & &
\end{tabular}




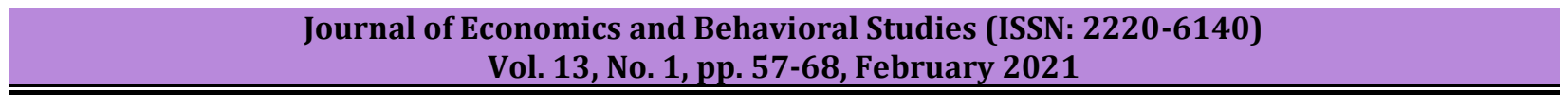

\begin{tabular}{llll}
\hline 14 & .079 & .440 & 99.806 \\
15 & .024 & .136 & 99.942 \\
16 & .008 & .043 & 99.985 \\
17 & .003 & .015 & 100.000 \\
18 & $-2.446 E-016$ & $-1.359 E-015$ & 100.000 \\
\multicolumn{4}{l}{ Extraction Method: Principal Component Analysis. } \\
\hline
\end{tabular}

From the foregoing, 6 components with eigenvalues greater than 1.0 were extracted, and all explained $79.647 \%$ of the total variation. The first component/factor had a variation contribution of $27.657 \%$, while the second component had a variation contribution of $16.751 \%$. The third component had a variance contribution of $11.397 \%$, and the fourth component a contribution of $9.478 \%$, the fifth had a variance of $7.612 \%$ and the sixth had a variance of $6.751 \%$. The corresponding scree plot is presented below.

Figure 5: Scree Plot - External Factors

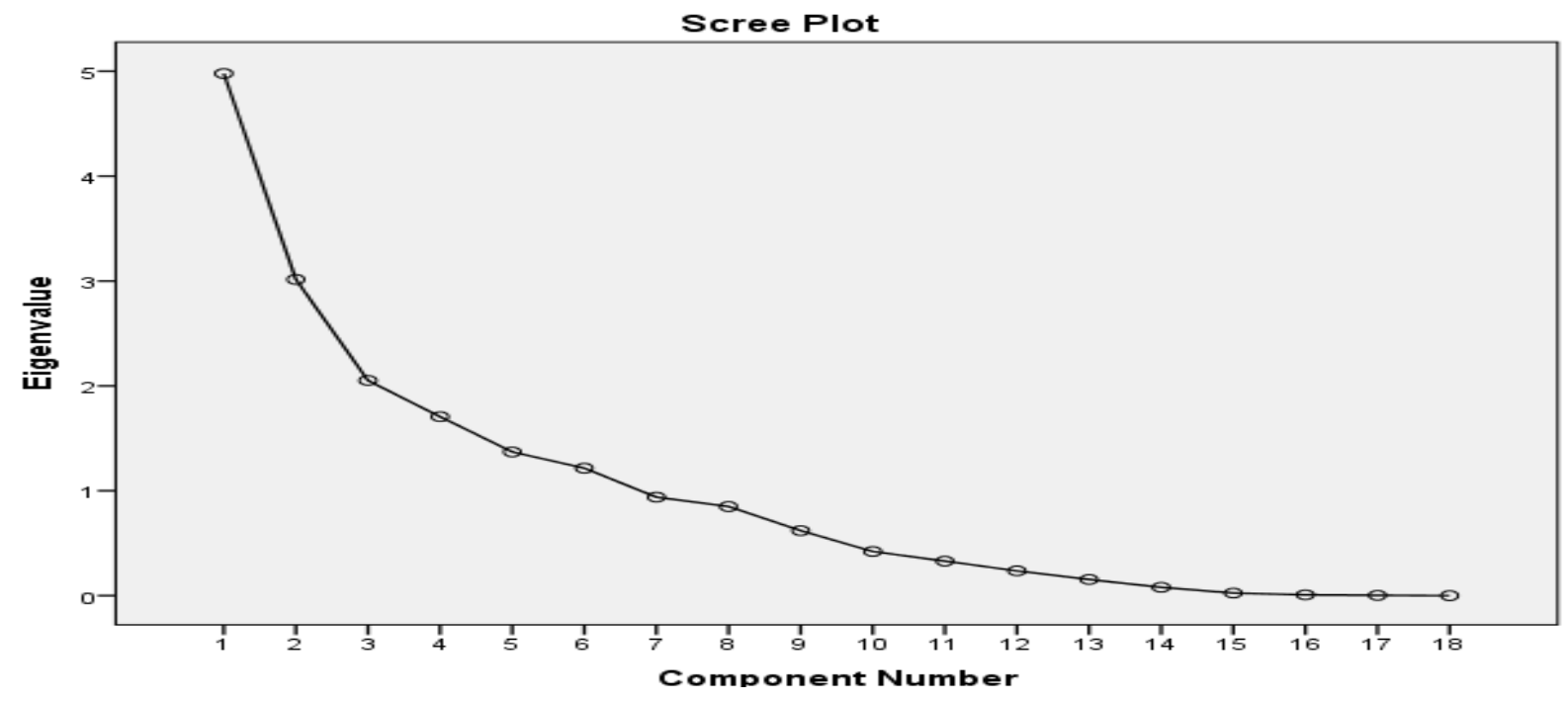

Table 4: Rotated Component Matrix

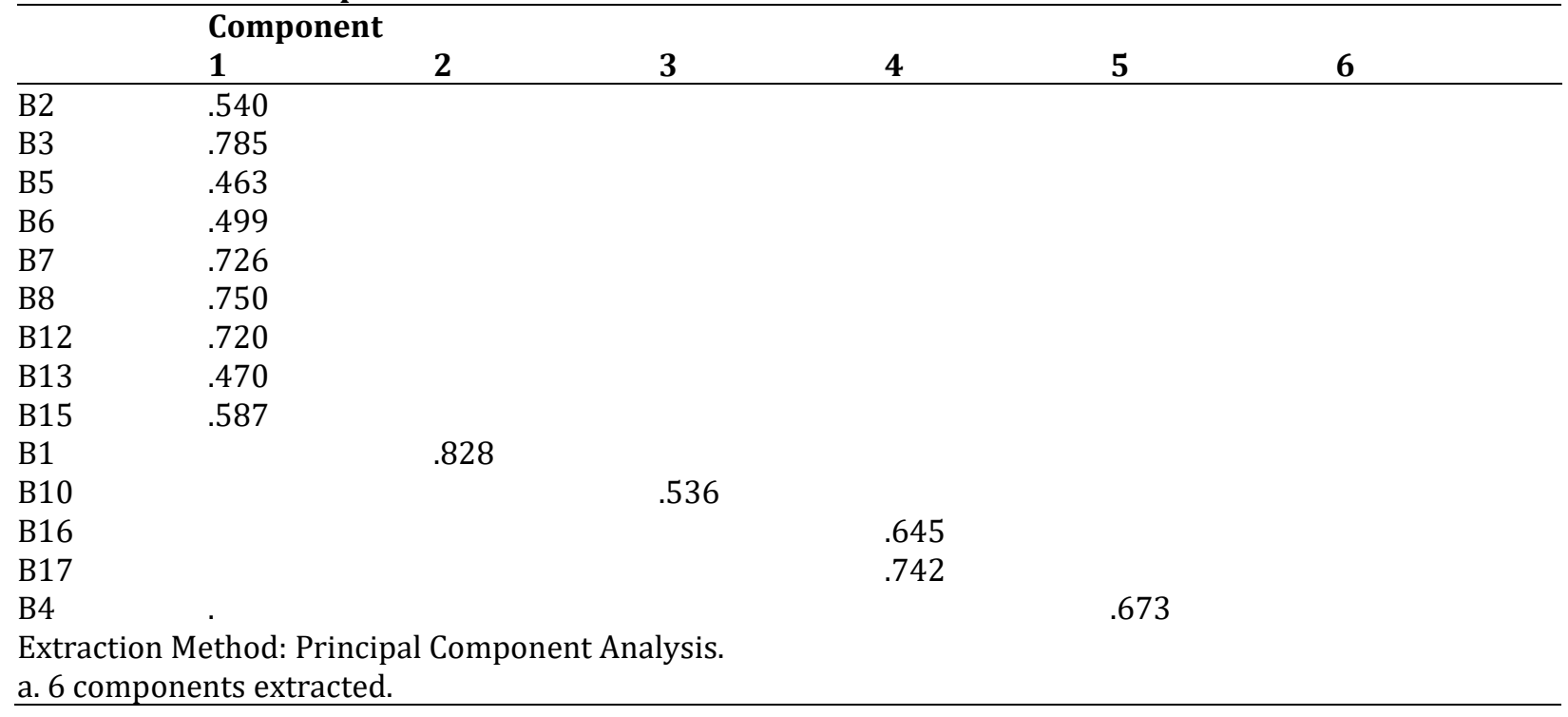


From the analysis, it can be concluded that there were essentially 6 factors that were behind the current funding in the mining sector of Zimbabwe and these mechanisms are: Project finance; Financing from private equity funds; Convertible loans; Public bonds; Corporates bonds and Government bonds.

Analysis of Factors: Factors influencing investment in the mining sector.

Table 5: Factors Influencing Investment in the Mining Sector

\begin{tabular}{lllllll}
\hline Factors influencing Investment & \multicolumn{2}{l}{ Symbol N } & \multicolumn{2}{l}{ Minimum Maximum } & Mean & $\begin{array}{l}\text { Std. } \\
\text { Deviation }\end{array}$ \\
\hline Politics & C1 & 20 & 4.00 & 5.00 & 4.9000 & .30779 \\
Interest rate & C2 & 20 & 3.00 & 5.00 & 4.2500 & .71635 \\
Royalty tax & C3 & 20 & 1.00 & 5.00 & 3.4000 & 1.18766 \\
Business economic empowerment policies & C4 & 20 & 2.00 & 5.00 & 4.1500 & .87509 \\
Capital markets & C5 & 20 & 1.00 & 5.00 & 3.7000 & 1.08094 \\
Venture capital incentives & C6 & 20 & 1.00 & 5.00 & 2.9000 & 1.11921 \\
Bank lending criteria & C7 & 20 & 4.00 & 5.00 & 4.3000 & .47016 \\
Asset exit clauses & C8 & 20 & 1.00 & 4.00 & 3.1500 & .98809 \\
Venture capital incentive & C9 & 20 & 1.00 & 4.00 & 2.8500 & 1.08942 \\
Technical information & C10 & 20 & 2.00 & 5.00 & 3.7500 & 1.16416 \\
Skilled and technical staff & C11 & 20 & 2.00 & 5.00 & 3.4000 & .88258 \\
Labor issues & C12 & 20 & 1.00 & 5.00 & 3.3000 & 1.08094 \\
\hline Then
\end{tabular}

The analysis from the table above was done using the key given below.

\begin{tabular}{lllll}
\hline $\mathbf{1}$ & $\mathbf{2}$ & $\mathbf{3}$ & $\mathbf{4}$ & $\mathbf{5}$ \\
\hline Not at all influential & Slightly influential & $\begin{array}{l}\text { Somewhat } \\
\text { influential }\end{array}$ & Very influential & $\begin{array}{l}\text { Extremely } \\
\text { influential }\end{array}$ \\
\hline
\end{tabular}

Table 5 shows that respondents agreed that the following factors are very influential to the investment in the mining sector; Interest rate, Business economic empowerment policies, bank lending criteria, Technical information whereas Politics was agreed to be extremely influential. The factors which were somewhat influential were Royalty tax, Venture capital incentives, Asset exit clauses, Venture capital incentive, Skilled and technical staff and Labor issues.

The Factors Influencing Funding Mechanisms in Mining: This section provides an analysis of the factors influencing funding of mining organizations and also how these factors affected anticipated funding either positively or negatively.

Table 6: Factors Influencing Funding Mechanisms

\begin{tabular}{llllll}
\hline Factors influencing funding & $\mathbf{N}$ & Minimum & Maximum & Mean & Std. Deviation \\
\hline C1A & 6 & $10,000,000$ & $35,000,000$ & $23,000,000$ & $8,717,797.97$ \\
C2A & 3 & $4,000,000$ & 10000000 & $8,000,000$ & $3,464,101.62$ \\
C3A & 1 & $30,000,000$ & $30,000,000$ & $30,000,000$ &. \\
C4A & 3 & $15,000,000$ & $30,000,000$ & $24,000,000$ & $7,937,253.93$ \\
C5A & 1 & $30,000,000$ & $30,000,000$ & $30,000,000$ &. \\
C6A & 0 & & & & \\
C7A & 5 & $7,000,000$ & $20,000,000$ & $11,400,000$ & $5,176,871.64$ \\
C8A & 0 & & & & \\
C9A & 0 & & & & \\
C10A & 5 & $10,000,000$ & $30,000,000$ & $7,080,000$ & $1,282,727.67$ \\
C11A & 3 & $3,500,000$ & $10,000,000$ & $7,833,333$ & $3,752,776.75$ \\
C12A & 1 & $10,000,000$ & $10,000,000$ & $10,000,000$ &. \\
\hline Ta 6 .
\end{tabular}

Table 6 shows that the factors influencing funding options in the funding options in the mining sector were $\mathrm{C} 1 \mathrm{~A}, \mathrm{C} 2 \mathrm{~A}, \mathrm{C} 3 \mathrm{~A}, \mathrm{C} 4 \mathrm{~A}, \mathrm{C} 5 \mathrm{~A}, \mathrm{C} 7 \mathrm{~A}, \mathrm{C} 10 \mathrm{~A}, \mathrm{C} 11 \mathrm{~A}$ and C12A with each respective factor attributable to an amount of 
23 million, 8 million, 30 million, 24 million, 30 million, 11.4 million, 7 million, 7.8million and 10 million of anticipated funding. The mid-tier range of 7 million -30 million of anticipated funding also points out that the factors are generally revolving around funding meant for recapitalization and sustenance which is not excessively high when compared to new project development in the sector. Table 6 exposes that the factors with the highest frequency thus influence were found to be $\mathrm{C} 1 \mathrm{~A}, \mathrm{C7}$ a and C10A namely, politics, bank lending criterion and technical information. The history of political unrest in Zimbabwe weighs in on the high level of country risk which impacts available funding.

Table 7: Positive Effect

\begin{tabular}{|c|c|c|c|c|c|c|c|c|c|}
\hline & \multirow{2}{*}{$\begin{array}{l}\text { N } \\
\text { Statistic }\end{array}$} & \multicolumn{3}{|c|}{ Minimum Maximum Mean } & \multirow{2}{*}{$\begin{array}{l}\text { Std. } \\
\text { Deviation } \\
\text { Statistic }\end{array}$} & \multicolumn{2}{|c|}{ Skewness } & \multicolumn{2}{|c|}{ Kurtosis } \\
\hline & & Statistic & Statistic & Statistic & & Statisti & $\begin{array}{l}\text { Std. } \\
\text { Error }\end{array}$ & Statistic & $\begin{array}{l}\text { Std. } \\
\text { Error }\end{array}$ \\
\hline$\overline{\mathrm{C} 1 \mathrm{PC}}$ & 20 & 0 & 0 & .00 & .000 & . & & . & \\
\hline $\mathrm{C} 2 \mathrm{P}$ & 20 & 0 & 1 & .15 & .366 & 2.123 & .512 & 2.776 & .992 \\
\hline C3P & 20 & 0 & 1 & .10 & .308 & 2.888 & .512 & 7.037 & .992 \\
\hline C4P & 20 & 0 & 1 & .15 & .366 & 2.123 & .512 & 2.776 & .992 \\
\hline C5P & 20 & 0 & 1 & .20 & .410 & 1.624 & .512 & .699 & .992 \\
\hline C6P & 20 & 0 & 1 & .10 & .308 & 2.888 & .512 & 7.037 & .992 \\
\hline C7P & 20 & 0 & 1 & .25 & .444 & 1.251 & .512 & -.497 & .992 \\
\hline $\mathrm{C} 8 \mathrm{P}$ & 20 & 0 & 1 & .05 & .224 & 4.472 & .512 & 20.000 & .992 \\
\hline C9P & 20 & 0 & 1 & .10 & .308 & 2.888 & .512 & 7.037 & .992 \\
\hline C10P & 20 & 0 & 1 & .30 & .470 & .945 & .512 & -1.242 & .992 \\
\hline C11P & 20 & 0 & 1 & .30 & .470 & .945 & .512 & -1.242 & .992 \\
\hline $\mathrm{C} 12 \mathrm{P}$ & 20 & 0 & 1 & .15 & .366 & 2.123 & .512 & 2.776 & .992 \\
\hline
\end{tabular}

Scale $1=$ Yes, $0=$ No

The table above shows that the factors with the highest scores were C11P $(0.30), \mathrm{C} 10 \mathrm{P}(0.30), \mathrm{C} 7 \mathrm{P}(0.25)$ and C5P (0.20). The factors which recorded a positive impact were skilled and technical staff, Technical information, bank lending criteria and Capital markets.

Table 8: Negative Effect

\begin{tabular}{|c|c|c|c|c|c|c|c|c|c|}
\hline & \multirow{2}{*}{$\begin{array}{l}\mathbf{N} \\
\text { Statistic }\end{array}$} & \multirow{2}{*}{$\begin{array}{l}\text { Minimum } \\
\text { Statistic }\end{array}$} & \multirow{2}{*}{$\begin{array}{l}\text { Maximum } \\
\text { Statistic }\end{array}$} & \multirow{2}{*}{$\begin{array}{l}\text { Mean } \\
\text { Statistic }\end{array}$} & \multirow{2}{*}{$\begin{array}{l}\text { Std. } \\
\text { Deviation } \\
\text { Statistic }\end{array}$} & \multicolumn{2}{|c|}{ Skewness } & \multicolumn{2}{|l|}{ Kurtosis } \\
\hline & & & & & & Statistic & $\begin{array}{l}\text { Std. } \\
\text { Error }\end{array}$ & Statistic & $\begin{array}{l}\text { Std. } \\
\text { Error }\end{array}$ \\
\hline $\mathrm{C} 1 \mathrm{~N}$ & 20 & 0 & 1 & .75 & .444 & -1.251 & .512 & -.497 & .992 \\
\hline $\mathrm{C} 2 \mathrm{~N}$ & 20 & 0 & 1 & .45 & .510 & .218 & .512 & -2.183 & .992 \\
\hline C3N & 20 & 0 & 1 & .15 & .366 & 2.123 & .512 & 2.776 & .992 \\
\hline $\mathrm{C} 4 \mathrm{~N}$ & 20 & 0 & 1 & .35 & .489 & .681 & .512 & -1.719 & .992 \\
\hline C5N & 20 & 0 & 1 & .10 & .308 & 2.888 & .512 & 7.037 & .992 \\
\hline C6N & 20 & 0 & 0 & .00 & .000 & . & . & . & \\
\hline C7N & 20 & 0 & 1 & .40 & .503 & .442 & .512 & -2.018 & .992 \\
\hline C8N & 20 & 0 & 1 & .15 & .366 & 2.123 & .512 & 2.776 & .992 \\
\hline C9N & 20 & 0 & 0 & .00 & .000 & . & . & . & \\
\hline C10N & 20 & 0 & 1 & .30 & .470 & .945 & .512 & -1.242 & .992 \\
\hline $\mathrm{C} 11 \mathrm{~N}$ & 20 & 0 & 1 & .05 & .224 & 4.472 & .512 & 20.000 & .992 \\
\hline $\mathrm{C} 12 \mathrm{~N}$ & 20 & 0 & 1 & .05 & .224 & 4.472 & .512 & 20.000 & .992 \\
\hline $\begin{array}{l}\text { Valid } \\
\text { (listwise) }\end{array}$ & $\mathrm{N}_{20}$ & & & & & & & & \\
\hline
\end{tabular}




\section{Conclusion and Recommendations}

Conclusion: The study concludes that the funding mechanisms being used in the mining sector of Zimbabwe are project finance, finance by private equity, public bonds, corporate bonds and bank loans. The study concluded that funding will lead to an increase in mining production improvement in product quality, increase in profitability, Infrastructural development, and increase in mining exports, increase in new technologies and increase in GDP.

\section{Recommendations}

Royalty Agreements: It is recommended that the mining sector should do some Royalty agreements. This is financing based on the output produced. It is facilitated through upfront payment of funding required with repayment later based on units produced or percentage of products value or profits realized or revenues generated from the mining business. Royalty agreements are a very attractive source of finance, which offers benefits non-dilutive capital or shareholding, non-controlling on company share capital, and deferred repayment based on mining production and revenues. Royalty arrangements can be ideal for struggling mining companies and the findings from their study proved that royalty arrangements cause mining companies to improve their productivity.

Escrow Accounts: Escrow account arrangement can work in high-risk and high depressed economies. Operating an escrow account with an international guarantee may reduce the fear of high risk by investors or funders. This will provide the necessary working capital requirements for mining operations. This would work positively for Zimbabwe as the country is poorly rated in terms of risk as it removes the fear of financiers.

Streaming Arrangements: Streaming arrangements can be used by this sector. It involves financing through the supply of mineral outputs. Financiers would sign contracts to fund the mining operations with repayment based on the supply of minerals at an agreed price for a certain period. Streaming arrangements are effective funding mechanisms for mining companies in a depressed economy.

Joint Ventures: The sector can use a Joint venture which is a contractual agreement between partners for mutual benefits through sharing funding costs, risks or rewards. Mining companies should identify partners with a strong financial base to fund the operations during the time of need in return for an agreed share of revenues or profits for a specified period. Therefore, the agreements should specify the exit strategy to the joint venture to avoid disputes and conflicts.

Equipment Financing: The sector can also use Equipment financing. Assets can be used to raise finance in a mining company that is seeking bank loans based on critical assets available in the mining company. These assets act as security to the financiers.

\section{References}

African Development Bank. (2014). 2005-2009 Country strategy paper. Windhoek: Government of the Republic of Namibia.

Agénor, P. R. \& Montiel, P. J. (2009). Development macroeconomics. Princeton, New Jersey: Princeton University Press.

Bankers Association of Zimbabwe. (2014). Accessing finance in a depressed economy. Bulawayo: Mine Entra 2014.

Chamber of Mines. (2015). State of the Mining Industry Survey Report, Harare, Zimbabwe.

Chamber of Mines. (2015). Proceedings of the 77th Chamber of Mines 2016 Annual General Meeting, Victoria Falls, May 2016

Chidhakwa, W. (Hon) (2016). Ministers Address. Proceedings of the 77th Chamber of Mines 2016 Annual General Meeting, Victoria Falls, May 2016.

Eita, J. H. \& Du Toit, C. B. (2007). Explaining investment behavior of the Namibian economy. A conference paper. Pretoria: University of Pretoria. 
Ferderer, J. P. (2009). The impacts of uncertainty on aggregate investment spending: An empirical analysis. Journal of Money, Credit and Banking, 25(1)30-48.

Gawlik, L. (2008). Construction and verification of an econometric model to determine linear relationship between coal acquisition cost and production volume. Mineral Raw Materials Management, 24(1/1), $27-44$.

Grossman, T. T. (2012). A Thoroughly Modern Resource Curse? The New Natural Resource Policy Agenda and the Mining Revival in Peru, IDS Working Paper 300, Brighton, Institute of Development Studies.

Hsu, I. C., Lin, C. Y. Y., Lawler, J. J. \& Wu, S. H. (2007). Towards a model of organizational human capital development: Preliminary evidence from Taiwana. Asia Pacific Business Review, 32(2), 251-275.

Keynes, J. M. (1936). The general theory of employment, interest, and money. United Kingdom: Macmillan Cambridge University Press.

Leedy, P. D. \& Ormrod, J. E. (2001). Practical Research: Planning and design (7th Ed,). Pearson Educational International and Prentice Hall: New Jersey.

Leeman, A. (2006). Foreign investment in Russia: Reform and Regulation. New York: McGraw-m Hill Irwin.

McCann, M. (2014). Funding mechanisms in the African region. Accountancy Journal, 1(2), 20-35.

McMann, A. (2010). Innovative Funding Mechanisms. Southern African Institute of Mining and Metallurgy, $2(4) 18$.

Meyer, P. (2014) Impact and development in local economies based on mining; the case of Chilean II Region, Resources policy, 27,119-134.

Mothomogolo, J. (2012). Development of innovative funding mechanisms for mining start-pus: A South African Case. The Southern African Institute of Mining and Metallurgy, Platinum.

Muganyi, T. (2016). Chamber of Mines President Address. Proceedings of the $77^{\text {th }}$ Chamber of Mines 2016 Annual General Meeting Speech presentation, Victoria Falls, May 2016, Zimbabwe.

Mutwiwa, m. \& Fondo, K. (2015). Factors Influencing Investment in the Mining Sector in Kenya: A Case Study of Base Titanium in Kwale, County International Journal of Science and Research, 10(4), 12-20.

Nghifenwa, N. (2009). Factors influencing investment: A case study of the Namibian economy: Windhoek

Pandey, I. M. (2008). Financial Management. (8th Edition), French forest NSW: Pearson Education Australia / Practice Hall. The Review of Economic Studies, 61(2), 197-222.

Selvarajan, T. T., Ramamoorthy, N., Flood, P. C, Guthrie, J. P., MacCurtin, S. J. \& Liu, W. (2007). The role of human capital philosophy in promoting firm innovativeness and performance: Test of a causal model. International Journal of Human Resources Management, 18(8), 1456-1470.

The Global Mining Finance Guide. (2012).

Tobin, J. (1969). A general equilibrium approach to monetary theory. Journal of Money, Credit, and Banking, $1(1), 15-29$.

Vale, I. (2012). Classical, Keynes' and neoclassical investment theory - a synthesis. United Kingdom: Oxford Economic Papers, 38(2), 305-316.

Vallerrie, D. N. (2010). Basic econometrics. New York: McGraw-Hill/Irwin.

Wang, D. W. (2012). Tax policy and investment behavior. The American Economic Review, 57(3), 391-414.

Zhu, D. (2011). Private investment in developing countries: An empirical analysis. Washington, IMF staff papers, 38(1). 